\title{
CENTRAL AND PERIPHERAL NERVOUS COMPLICATIONS OF DENTAL TREATMENT
}

\author{
EVA OLOVSSON ROSSITTI*
}

SUUMARY - This review outlines the complications involving the central or peripheral nervous system arising from dental procedures reported in the last decade. By far the commonest complications were related to intraoperative mechanical peripheral nerve injury. Trauma to branches of the mandibular nerve occuring during oral operations may potentially result in varying degrees of hypoesthesia, paresthesia, dysesthesia or in chronic pain syndromes. An increase in malpractice suits related to such a complication has been recognized in the late years. A warning of the possibility of occurrence of this complication should to be given to all patients undergoing risky procedures as part of the process of obtaining informed consent to operation. Mandibular third molar extraction seems to be alone the most hazardous procedure related to mechanical nerve injuries and also with anesthesiological accidents. Severe but rather infrequent infectious (meningitis, brain abscess and cavernous sinus thrombophlebitis) and anesthesiological complications (occular and facial palsies, optic nerve injury and complications related to general anesthesia) were also reported in this period.

KEY WORDS: anesthesia, dental, adverse effects; dental, complications; dentistry, operative; inferior alveolar nerve, injury; lingual nerve, injury; nerve block, adverse effects; sensation disorders, etiology; third molar; tooth extraction, adverse effects.

\section{Complicações de tratamento dentário afetando o sistema nervoso}

RESUMO - Complicações, ou eventos inesperados e indesejáveis associados a terapia de uma dada condiçāo, podem ser particularmente incapacitantes quando afetam o sistema nervoso. A proximidade de cavidade craniana e a rica inervação dos tecidos orais representam risco potencialmente alto de disseminação de infecções para o sistema nervoso central e de lesões de troncos nervosos em procedimentos dentários. Em vista do aumento da ocorrência de processos para compensaçāo financeira após tais complicações, é provável que parcela considerável desses pacientes venham a ser examinados por neurologistas. As complicaçōes de tratamento dentário afetando o sistema nervoso central e periférico referidas na literatura (1982-1994) são tema desta revisão. As complicações mais comuns foram as lesões dos ramos da divisão mandibular do nervo trigêmeo provocadas por trauma mecânico. A extração do terceiro molar mandibular foi o procedimento dentário com maior morbidade tanto com relação a trauma mecânico quanto a acidente anestésico. Nesse procedimento o nervo lingual pode ser traumatizado em $11 \%$ a $15 \%$ das operações e o nervo alveolar inferior em $4,4 \%$ a $5,5 \%$. Os sintomas são permanentes em $0,5 \%$ a $1,0 \%$. Outras complicações potencialmente severas porém infrequentes no período estudado foram as infeç̧ões (meningite, tromboflebite do seio cavemoso e abscesso cerebral) e as complicą̧ões anestésicas (oftalmoplegia, paralisia facial e complicações da anestesia geral).

PALAVRAS-CHAVE: anestesia dental, complicações; bloqueio nervoso, complicaçðes; cirurgia bucomaxilofacial; dor facial, etiologia; extraçāo dental, complicaçōes; nervo alveolar inferior; nervo lingual; terceiro molar.

*Dentist. Aceite: 4-janeiro-1995.

Eva Olovsson Rossitti - Nordenskiöldsgatan 6 - S-41309 Göteborg - Sweden. 
Complications are unexpected and undesirable events associated with management of disease conditions. Complications are particularly disabling when they involve the nervous system. In Operative Dentistry, the vicinity to the cranial cavity and the abundance of nerve branches in the oral structures represent definite risks of spreading of infection to the former and of immediate injury to the latter.

The objective of this paper is to outline the complications involving the central or peripheral nervous system that may arise from dental procedures in the current practice.

\section{METHODS AND RESULTS}

A search was done in the literature concerning the complications of dental treatment. The sources were MEDLINE and Science Citation Index from 1982 to September 1994, and Current Contents for the last eight weeks.

The articles in regard to complications involving the nervous system were selected. Such reports are summarized in Table 1.

Table 1. Central and peripheral nervous complications of dental treatment.

\begin{tabular}{|c|c|c|}
\hline Complication & Remarks & References \\
\hline Meningitis & Dental extraction & $9,12,19,29$ \\
\hline Meningococcemia & Dental extraction & 24 \\
\hline Orbital celluttis and meningitis & Dental extraction & 3 \\
\hline Cavernous sinus thrombophlebitis & Dental extraction & 33 \\
\hline Brain abscess & Dental extraction & 22 \\
\hline Amaurosis & Inferior dental nerve block & 3 I \\
\hline \multirow{2}{*}{$\begin{array}{l}\text { Mechanical nerve injury (lingual or } \\
\text { inferior alveolar nerve) }\end{array}$} & Extraction of the mandibular third molar & $2,6,7,8,16,18,20,21,23,26,28,30,32$ \\
\hline & $\begin{array}{l}\text { Mandibular ramus sagittal split osteotomy } \\
\text { and fixation }\end{array}$ & 14 \\
\hline Altered sensation (nonspecific) & Mandibular implant surgery & 11 \\
\hline $\begin{array}{l}\text { Altered sensation (menthal nerve } \\
\text { territory) }\end{array}$ & Over-extension of root canal filling & 13 \\
\hline Bell's palsy & $\begin{array}{l}\text { Occurring twice within } 24 \text { hours after } \\
\text { dental treatment }\end{array}$ & 27 \\
\hline Peripheral facial nerve paralysis & Upper dental nerve block & 1,20 \\
\hline Ocular palsy & Inferior dental nerve block & 10,15 \\
\hline $\begin{array}{l}\text { Combined peripheral facial nerve and } \\
\text { ocular palsy }\end{array}$ & Inferior dental nerve block & 4 \\
\hline Rhabdomyolisis (fatal) & Anes thetical complication & 5 \\
\hline
\end{tabular}

\section{COMMENTS}

\section{Complications affecting the central nervous system}

I.I Infections. Dental procedures are frequently followed by bacteremia, implying a potential risk for infective endocarditis and for other kinds of blood-borne spreading. Bacteria obtained in blood cultures following dental manipulation are similar to the bacteria present in the normal mouth flora, for instance oral streptococci. Infectious complications in the nervous system such as meningitis ${ }^{39.12 .19 .24 .29}$, brain abscess ${ }^{22}$, cavernous sinus thrombophlebitis ${ }^{33}$ and orbital cellulitis ${ }^{3}$ are presently uncommon due to the preventive use of antibiotics in high-risk procedures.

1.2. Optic nerve injury. Amaurosis was reported in a young patient as a result of local anesthesia by mandibular nerve block ${ }^{31}$. The mechanism of injury was presumably intravascular injection of 
local anesthetics. Loss of vision was ipsilateral to the block and the patient presented with subsequent atrophy of the optic nerve.

\section{Peripheral nerve injuries}

2.1. Related to local nerve block. The occurrence of ocular palsy ${ }^{10,15}$ is presumably related to arterial puncture and intra-arterial injection of local anesthetics. Peripheral facial nerve paralysis is known to occur after local dental block. Most of the patients with this complication develop prosoplegia immediately after dental anesthesia and resolve completely within 12 hours. Transient prosoplegia is as a rule related to inferior dental block. The uncommon development of peripheral facial nerve paralysis after upper dental block has been reported ${ }^{\prime}$. A patient was reported to present both facial and oculomotor nerve palsies during the same procedure 4 . Bell's palsy was reported to occur twice in the same patient within 24 hours of a dental treatment, two years appart ${ }^{27}$; this observation is intriguing, but its casual relation to the dental treatment is merely speculative.

2.2. Mechanical injuries. Trauma to branches of the mandibular nerve may occur during oral operation and it may potentially result in varying degrees of hypoesthesia, paresthesia, dysesthesia or in chronic pain syndromes. Injury of the inferior alveolar and lingual nerves occur mostly in relation to third molar extraction $2,6,7,8,16,18,20,21,23,26,28,30,32$ and procedures on the mandibular ramus ${ }^{14}$. The frequency of inferior alveolar nerve trauma during mandibular third molar removals is between

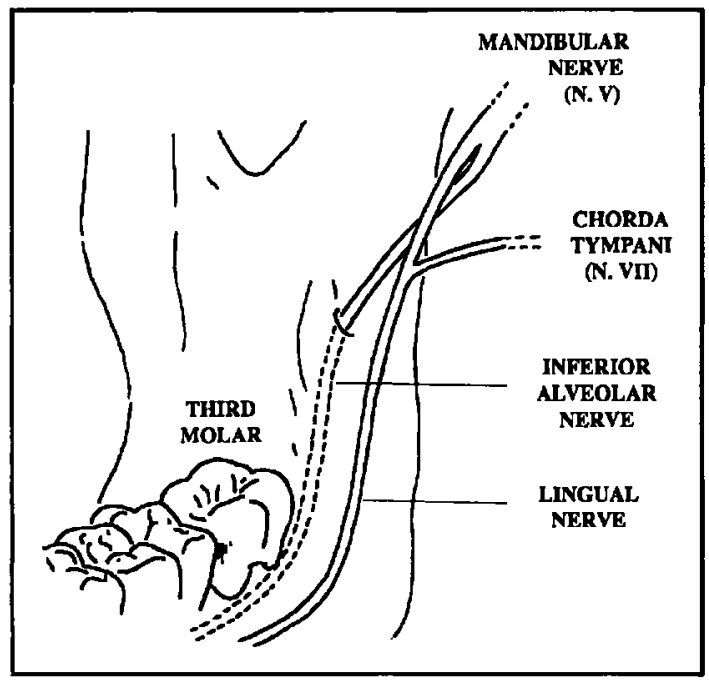

Fig 1. Schematic representation of the inner aspect of the lower jaw showing the site of the inferior alveolar and linguai nerves relative to the third molar. There are considerable variations of the normal anatomy, and thus the precise site of the lingual nerve cannot be ascertained pre-operatively. The site of the inferior alveolar nerve may be extablished indirectly by observing the root configuration and intimacy to the mandibular canal in plain radiographs (stereographs may be necessary in some cases). In the abscence of infection, removal of only the crown of a lower third molar may be attempted in patients in which root anatomy is complicated, in order to avoid nerve damage $e^{17}$. Retained third molars in direct contact with the mandibular canal is about 50\% more frequent in women than in men. 
$4.4 \%$ and $5.5 \%$, and the corresponding range for the lingual nerve is as high as $11 \%$ to $15 \%^{2,16,25}$. In most of the cases such a complication is temporary. In an authoritative report ${ }^{2}$ of 1,117 consecutive oral surgical procedures by a variety of operators to remove a third molar the incidence of lingual nerve damage was $11 \%$; more than half of the patients made a full recovery within 6 weeks, and most of the rest recovered within 36 weeks; permanent symptoms were present in $0.5 \%$. Age and sex do not seem to be risk factors for the development of chronic discomfort ${ }^{26}$. Minor nerve injuries due to mechanical stress leading to permanent altered sensation occurs in over one third of the patients

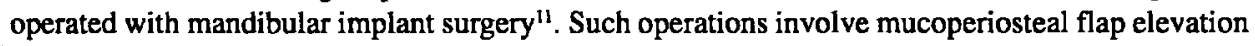
and bone removal during site preparation and similiar oral surgical procedures are known to have approximately the same incidence of this complication. Over-extension of root canal filling was reported to provoke altered sensation in the territory of the mental nerve in a single report ${ }^{13}$.

3. Complication associated to muscular dystrophy. As a rule, muscular diseases imply in higher anesthetical risk. A 6-year-old boy with Becker muscular dystrophy was reported to develop a fatal complication during general anesthesia for dental treatment ${ }^{5}$. The patient had a cardiac arrest associated with acute rhabdomyolisis, hyperkalemia and hypocalcemia, and died four days later. The diagnosis of Becker muscular dystrophy had been done 15 months before the accident on the basis of elevated creatine kinase, dystrophin analysis, muscle biopsy and chromosome analysis. The patient was previously asymptomatic with exception for myoglobulinuria.

\section{CONCLUSION}

While rather severe infectious and anesthesiological complications affecting the nervous system were reported, such complications were very uncommon. The commonest nervous complications of dental treatment during the last decade were related to mechanical injury of peripheral nerves during the operations. An increase in malpractice suits related to such a complication has been recognized in the last yeras ${ }^{30}$. A retrospective questionnaire study carried out in Sweden revealed that less than $10 \%$ of the patients with iatrogenic nerve injury caused by dental treatment who claimed economical compensation were fully counscious of the risk ${ }^{26}$. Third molar extraction in the lower cheek was alone the most hazardous procedure connected with mechanical nerve injuries and also with anesthesiological accidents (Fig 1). The occurrence of lingual nerve injury is so frequent in third molar extraction that a warning of its possible occurrence should to the given to all patients undergoing such a procedure as part of the process of obtaining informed consent to operation.

Acknowledgement - To my husband Sandro Rossitti for stimulating criticism and support.

\section{REFERENCES}

1. Bemsen PL. Peripheral facial nerve paralysis after local upper dental anaesthesia. Eur Neurol 1993, 33:90-91.

2. Blackburn CW, Bramley PA. Lingual nerve damage associated with the removal of lower third molars. Br Dent J 1989, 167:103-107.

3. Bullock JD, Fleishman JA. Orbital cellulitis following dental extraction. Trans Am Ophthalmol Soc 1984, 82:111-133.

4. Burke RH, Adams JL. Immediate cranial nerve paralysis during removal of a mandibular third molar. Oral Surg Oral Med Oral Pathol 1987, 63:172-174.

5. Bush A, Dubowitz V. Fatal rhabdomyolysis complicating general anaesthesia in a child with Becker muscular dystrophy. Neuromusc Disord 1991, 1:201-204.

6. Cade TA. Paresthesia of the inferior alveolar nerve following the extraction of the mandibular third molars: a literature review of its causes, treatment, and prognosis. Mil Med 1992, 157:389-392.

7. Campbell RL. Shamanskin RG, Harkins SH. Assessment of recovery from injury to inferior alveolar and mental nerves. Oral Surg Oral Med Oral Pathol 1987, 64:519-526.

8. Carmichaels FA, McGowan DA. Incidence of nerve damage following third molar removal: a West of Scorland Oral Surgery Research Group Study. Br J Oral Maxillofac Surg 1992, 30:78-82.

9. Colville A, Davies W, Heneghan M, Goodwin A, Griffiths T. A rare complication of dental treatment: Streptococcus oralis meningitis. Br Dent J 1993, 175:133-134. 
10. Dryden JA. An unusual complication resulting from a Gow-Gates mandibular block. Compendium 1993, 14:94-98.

11. Ellies LG, Hawker PB. The prevalence of altered sensation associated with implant surgery. Int J Oral Maxillofac Implants 1993, 8:674-679.

12. Fernando IN, Phipps JS. Dangers of an uncomplicated tooth extraction: a case of Streptococcus sanguis meningitis. Br Dent J 1988, 165:220.

13. Gumru OZ, Yalcin S. Surgical treatment of paresthesia following over-extension of root canal filling material: a case report. J Nihon Univ Sch Dent 1991, 33:49-53.

14. Hegtvedt AK, Zuniga JR. Lingual nerve injury as a complication of rigid fixation of the saggital ramus osteotomy: report of a case. J Oral Maxillofac Surg 1990, 48:647-650.

15. Hotrabhavanond $P$, Meksupa L. A complication of inferior dental nerve block: temporary ocular palsy (English abstract). J Dent Assoc Thai 1989, 39:5-10.

16. Kipp DP, Goldstein BH, Weiss WW Jr. Dysesthesia after mandibular third molar surgery: a retrospective study and analysis of 1,377 surgical procedures. J Am Dent Assoc 1980, 100:185-192.

17. Knutsson K, Lysell L, Rohlin M. Postoperative status after partial removal of the mandibular third molar. Swed Dent J 1989, 13:15-22.

18. LaBanc JP, Epker BN. Serious inferior alveolar nerve dysesthesia after endodontic procedure: report of three cases. J Am Dent Assoc 1984, 108:605-607.

19. Longfield RN, Buescher ES. Streptococcus bovis meningitis following a dental procedure. JAMA 1982 , 247:2663.

20. Maranda G. Le dammage nerveux: un incident ou accident courant en médecine dentaire. J Can Dent Assoc 1985, 51:445-447.

21. Mason DA. Lingual nerve damage following lower third molar surgery. Int J Oral Maxillofacial Surg 1988, 17:290-294.

22. Mohler ER, Monahan B, Canty MD, Flockhart DA. Cerebral abscess associated with dental procedure in hereditary haemorrhagic telangiectasia. Lancet 1991, 338:508-509.

23. Mommaerts $M$, Jacobs W. La lésion du nerf lingual lors de l'extraction des dents de sagesse inferieures. Rev Belge Med Dent 1991, 46:27-46.

24. Pedersen LM, Madsen OR, Gutschik E. Septicaemia caused by an unusual Neisseria meningitidis species following dental extraction. Scand J Infect Dis 1993 25:137-139.

25. Rajasuo A. Third-molar-related problems in finnish conscripts: clinical status, microbiology and current treatment practice. Annales Medicinae Militaris Fenniae 1994, 2a:1-42.

26. Sandstedt P, Sörensen S, Bodin-Björkman I. Orala nervskador: enkätundersökning av ett försäkringsmaterial. Tandläkartidningen 1990, 82:661-670.

27. Shuaib A, Lee MA. Recurrent peripheral facial nerve palsy after dental procedures. Oral Surg Oral Med Oral Pathol 1990, 70:738-740.

28. Schmoker R, Rufenacht D, von Allmen G, Bronz G. Die iatrogene Läsion des Nervus lingualis als Komplikation bei der operativen Weisheitszhnentfernung. SSO Schweiz Monatsschr Zahnheilkd 1982, 92:916-921.

29. Storgaard M. Meningitis forarsaget af Capnocytophaga camimorsus med udvikling af erythema nodosum. Ugeskr Laeger 1992, 154:2437-2438.

30. Swanson AE. Removing the mandibular third molar: neurosensory deficits and consequent litigation. J Can Dent Assoc 1989, 55:383-386.

31. Tomazzoli-Gerosa L, Marchini G, Monaco A. Amaurosis and atrophy of the optic nerve: an unusual complication of mandibular-nerve anesthesia. Ann Ophthalmol 1988, 20:170-171.

32. Woffort DT, Miller RI. Prospective study of dysesthesia following odontectomy of impacted mandibular third molars. J Oral Maxillofacial Surg 1987, 45:15-19.

33. Yun MW, Hwang CF, Lui CC. Cavemous sinus thrombosis following odontogenic and cervicofacial infection. Eur Arch Otorhinolaryngol 1991, 248:422-424. 